\title{
Evolution of Nitrogen Compounds During Grape Ripening from Organic and Non-Organic Monastrell - Nitrogen Consumption and Volatile Formation in Alcoholic Fermentation
}

\author{
Teresa Garde-Cerdán ${ }^{1,2}$, Cándida Lorenzo ${ }^{1}$, Ana M. Martínez-Gil1 ${ }^{1}$, \\ José F. Lara ${ }^{1}$, Francisco Pardo ${ }^{3}$ and M. Rosario Salinas ${ }^{1}$ \\ ${ }^{1}$ Cátedra de Química Agrícola, E.T.S.I. Agrónomos, Universidad de Castilla-La Mancha, \\ Campus Universitario, 02071 Albacete, \\ ${ }^{2}$ Servicio de Investigación y Desarrollo Tecnológico Agroalimentario (CIDA) \\ Instituto de Ciencias de la Vid y del Vino \\ (CSIC-Universidad de La Rioja-Gobierno de La Rioja), La Rioja \\ ${ }^{3}$ Bodega San Isidro (BSI), Murcia, \\ Spain
}

\section{Introduction}

Presently, the wine consumers are more and more worried about to choose aliments harmless for health. For this reason, ecological agriculture is incremented its popularity. Today, the legislation says that ecological wines are those elaborated with ecological or organic grapes, that is to say, from grapes cultivated with limitations in the use of chemical fertilizers, insecticides and other pest control synthetic substances, but using sustainable agricultural practices such as cover crops and natural products such as compost (Moyano et al., 2009). The Monastrell variety, also known as Mourvedre, is the second red grape variety most cultivated in Spain, although is also cultivated in France, Australia, Portugal and United States, among others.

The nitrogen compounds of must are essential for growth and development of yeasts during the wine alcoholic fermentation as nitrogen is, after carbon, the second element utilized during their growth. The ammonium and amino acids are the main sources of nitrogen for Saccharomyces cerevisiae. The content of these compounds affects the kinetics of fermentation, as nitrogen-deficient musts can cause slow, sluggish and stuck fermentations (Bisson, 1991; Arias-Gil et al., 2007). For this reason, in many wineries it is common practice to add diammonium phosphate (DAP) to the must before the fermentation. However, it is important that this addition follows some criterion, since if large amounts of ammonium are added to the must can result in problems later on, such as risk of microbiological instability, with formation of biogenic amines and ethyl carbamate, which are negative compounds for wine quality (Moreno-Arribas \& Polo, 2009; Uthurry et al., 2007).

Moreover, the consumption of nitrogen compounds during alcoholic fermentation depends on the physicochemical properties of the must ( $\mathrm{pH}$, acidity, sugars, ...), on the grape variety, 
on the nitrogen composition of the must, on yeast and on the fermentation temperature, etc. (Barbosa et al., 2009; Bell \& Henschke, 2005; Bouloumpasi et al., 2002; Garde-Cerdán et al., 2011; Héberger et al., 2003; Henschke \& Jiranek, 1993; Valero et al., 2003). Although other factors as the cultivated systems (organic or non-organic) could also affect the nitrogen composition of must and their consumption during alcoholic fermentation and so, they could affect the formation of volatile compounds.

Higher alcohols, fatty acids, and esters are important compounds in the wine aroma, especially for grape neutral varieties. These varieties present low concentrations of varietal aromas, so their wine aroma quality is principally related to the volatile compounds produced during the alcoholic fermentation (Lambrechts \& Pretorius, 2000). The fermentative volatile compounds mainly come from sugar and amino acids metabolism of yeasts. S. cerevisiae yeast produces different quantities of aroma compounds in relation with the fermentation conditions and must initial composition, for example, yeast strain, temperature, grape variety, micronutrients, vitamins, additives and nitrogen composition of must (Carrau et al., 2008; Garde-Cerdán \& Ancín-Azpilicueta, 2008; Lorenzo et al., 2008; Ruiz-Larrea et al., 1998).

For all these reasons, the objectives of this work were: (a) to study the amino acid and ammonium evolution during ripening of grapes from organic and non-organic Monastrell variety. In this way, we could have information about the optimum harvest moment, in terms of nitrogen composition of the must, as this is a determinant factor to a proper development of alcoholic fermentation as well as to wine aroma quality; (b) to study the effect of the crop management in the consumption of nitrogen compounds during the alcoholic fermentation of the musts. The consumption of nitrogen compounds can be influenced, among other factors, by their initial concentration in the must, and in its turn can affect the formation of volatile compounds, and (c) to study the differences in the formation of volatile compounds during the alcoholic fermentation of organic and non-organic Monastrell grapes, because fermentative volatile compounds determine the aroma quality of young wines coming from neutral varieties.

\section{Methodology}

\subsection{Grapes}

Monastrell red grape variety cultivated in O.D. Jumilla (SE of Spain) under non-organic and organic agriculture was used. The plots had similar edaphoclimatic conditions as they are located in the same area. In the conventional agriculture system, Monastrell non-organic, the vineyards were cultivated in trellis and were fitted with a drip irrigation system. They were fertilized with liquid fertilizer NPK 8-4-10 (\%, w/w) (Agribeco, Spain), applied in total $250 \mathrm{~g}$ per vine. In the case of Monastrell organic the vineyards were cultivated in glass and were treated with fertilizer "cultivit ecológico" (Agribeco), consisting of dried granulated sheep manure, the composition of which was NPK 1.55-1.21-2.35 (\%, w/w), applying in total $200 \mathrm{~g}$ per vine. The organic system was not irrigated.

\subsection{Samples}

Samples from organic and non-organic Monastrell were collected during grape ripening. The sampling was carried out by choosing the first vine of the plot at random, of a row also chosen randomly, and then in the same row was collected one grape bunch out of every five 
vines, until completing ten samples. Bunches from north and south exposition, as well as to different height and depth within the same vine were selected, in order to ensure that the sampling was representative. Samples from organic and non-organic Monastrell were collected on August 8, August 23, September 5, September 19 and September 27 during the year 2007. To obtain the must samples, several grains of grapes were caught at random from bunches collected for each sample. The musts were obtained manually for further analysis of their contents in nitrogen compounds and oenological parameters.

\subsection{Vinification}

The grape was destemmed and crushed to obtain the must. For each sample (organic and non-organic Monastrell at September 27), $400 \mathrm{~mL}$ was used, which was divided into 2 aliquots as they were fermented-macerated in duplicate. Must were inoculated with active dry S. cerevisiae subsp. cerevisiae (U.C.L.M. S325, Springer Oenologie, France) in a proportion of $0.2 \mathrm{~g} / \mathrm{L}$ according to commercial recommendations. For this, $0.65 \mathrm{~g}$ of dry yeast was rehydrated in a sterile flask in $7.5 \mathrm{~mL}$ of distilled water with $0.07 \mathrm{~g}$ of sucrose (number of viable cells $/ \mathrm{mL} \geq 2 \times 10^{9}$ ); it was kept in this medium for $30 \mathrm{~min}$ at $35^{\circ} \mathrm{C}$. The musts were inoculated while being mixed to obtain a homogeneous distribution. Before fermentation, the musts were sulphited with potassium metabisulfite to a final total $\mathrm{SO}_{2}$ concentration of $70 \mathrm{mg} / \mathrm{L}$ in non-organic samples, and of $20 \mathrm{mg} / \mathrm{L}$ in organic samples. The fermentationsmacerations took place in glass fermenters with a capacity of $250 \mathrm{~mL}$ and with a lid with two outlets; one for sample extractions and the other with a $\mathrm{CO}_{2}$ trap to allow its exit and prevent the entrance of air during the alcoholic fermentation. The orifice for sample extraction was covered with a septum during the fermentation. The fermenters were placed over magnetic stirrers, to ensure a homogenous fermentation. The fermentations were carried out in a hot incubator at a controlled temperature of $28^{\circ} \mathrm{C}$. The evolution of the fermentation was followed by the daily measurement of sugars through the refraction index at $20^{\circ} \mathrm{C}$, using a refractometer $\mathrm{CT}$ (Sopelem, France). The samples were taken when the alcoholic fermentation was finished (reducing sugars $<2.5 \mathrm{~g} / \mathrm{L}$ ).

\subsection{Oenological parameters}

${ }^{\circ}$ Baumé, total acidity, volatile acidity, $\mathrm{pH}$, reducing sugars, and alcohol of different samples were measured using ECC (1990) methods. The color intensity was determined by sum of the absorbance at 420,520, and $620 \mathrm{~nm}$, being this parameter called "color index".

\subsection{Analysis of amino acids and ammonium by HPLC}

The analysis of ammonium and amino acids was made using the method described by Garde-Cerdán et al. (2009a). The derivatization of amino acids and ammonium was carried out by reaction of $1.75 \mathrm{~mL}$ of borate buffer $1 \mathrm{M}(\mathrm{pH}=9), 750 \mu \mathrm{L}$ of methanol (Merck, Darmstadt, Germany), $1 \mathrm{~mL}$ of sample (previously filtered), $20 \mu \mathrm{L}$ of internal standard (2aminoadipic acid, $1 \mathrm{~g} / \mathrm{L}$ ) (Aldrich, Gillingham, England) and $30 \mu \mathrm{L}$ of derivatization reagent diethyl ethoxymethylenemalonate (DEEMM) (Aldrich). The reaction of derivatization was done in a screw-cap test tube over $30 \mathrm{~min}$ in an ultrasound bath. The sample was then heated at $70-80^{\circ} \mathrm{C}$ for $2 \mathrm{~h}$ to allow complete degradation of excess DEEMM and reagent byproducts. The analyses were performed on an Agilent 1100 HPLC (Palo Alto, USA), with a photodiode array detector. Chromatographic separation was performed in an ACE HPLC column (C18-HL) (Aberdeen, Scotland) particle size $5 \mu \mathrm{m}(250 \mathrm{~mm} \times 4.6 \mathrm{~mm})$. Amino acids 
were eluted under the following conditions: $0.9 \mathrm{~mL} / \mathrm{min}$ flow rate, $10 \% \mathrm{~B}$ during 20 minutes, then elution with linear gradients from $10 \%$ to $17 \%$ B in 10 minutes, from $17 \%$ to $19 \% \mathrm{~B}$ in 0.01 minutes, maintained during 0.99 minutes, from $19 \%$ to $19.5 \% \mathrm{~B}$ in 0.01 minutes, from $19.5 \%$ to $23 \% \mathrm{~B}$ in 8.5 minutes, from $23 \%$ to $29.4 \%$ B in 20.6 minutes, from $29.4 \%$ to $72 \%$ B in 8 minutes, from $72 \%$ to $82 \%$ B in 5 minutes, from $82 \%$ to $100 \%$ B in 4 minutes, maintained during 3 minutes, followed by washing and reconditioning the column. Phase A, $25 \mathrm{mM}$ acetate buffer, $\mathrm{pH}=5.8$, with $0.4 \mathrm{~g}$ of sodium azide; phase $\mathrm{B}, 80: 20$ $(\mathrm{v} / \mathrm{v})$ mixture of acetonitrile and methanol (Merck). A photodiode array detector monitored at 280,269 and $300 \mathrm{~nm}$ was used to detection. The volume of sample injected was $50 \mu \mathrm{L}$. The target compounds were identified according to the retention times and the UV-vis spectral characteristics of corresponding standards (Aldrich) derivatizated. Quantification was done using the calibration graphs of the respective standards in $0.1 \mathrm{~N} \mathrm{HCl}$, which underwent the same process of derivatization that the samples. The analysis of amino acids and ammonium was done in duplicate, so the results showed for amino acids and ammonium in the grape samples were the mean of 2 analyses and the results for the wine samples were the mean of 4 analyses, as the fermentations were done in duplicate.

\subsection{Analysis of volatile compounds by GC-MS}

The fermentative volatile compounds were analysed following the method described by Garde-Cerdán et al. (2009b). Compounds were extracted by introducing the polydimethylsiloxane coated stir bar $(0.5 \mathrm{~mm}$ film thickness, $10 \mathrm{~mm}$ length, Twister, Gerstel, Mülheim and der Ruhr, Germany) into $10 \mathrm{~mL}$ of sample, to which $100 \mu \mathrm{L}$ of internal standards $\gamma$-hexalactone and 3-methyl-1-pentanol solution at $1 \mu \mathrm{L} / \mathrm{mL}$, both in absolute ethanol (Merck) was added. Samples were stirred at $500 \mathrm{rpm}$ at room temperature for $60 \mathrm{~min}$. The stir bar was then removed from the sample, rinsed with distilled water and dried with a cellulose tissue, and later transferred into a thermal desorption tube for GC-MS analysis. In the thermal desorption tube, the volatile compounds were desorbed from the stir bar at the following conditions: oven temperature at $330^{\circ} \mathrm{C}$; desorption time, $4 \mathrm{~min}$; cold trap temperature, $-30^{\circ} \mathrm{C}$; helium inlet flow 45 $\mathrm{mL} / \mathrm{min}$. The compounds were transferred into the Hewlett-Packard LC 3D mass detector (Palo Alto, USA) with a fused silica capillary column (BP21 stationary phase $30 \mathrm{~m}$ length, $0.25 \mathrm{~mm}$ i.d., and $0.25 \mu \mathrm{m}$ film thickness; SGE, Ringwood, Australia). The chromatographic program was set at $40^{\circ} \mathrm{C}$ (held for $5 \mathrm{~min}$ ), raised to $230^{\circ} \mathrm{C}$ at $10^{\circ} \mathrm{C} / \mathrm{min}$ (held for $15 \mathrm{~min}$ ). The total time analysis was 36 minutes. For mass spectrometry analysis, electron impact mode (EI) at $70 \mathrm{eV}$ was used. The mass range varied from 35 to $500 \mathrm{u}$ and the detector temperature was $150^{\circ} \mathrm{C}$. Identification was carried out using the NIST library and by comparison with the mass spectrum and retention index of chromatographic standards (Sigma-Aldrich, Madrid, Spain). Quantification was based on five-point calibration curves of respective standards in synthetic wine. The analysis of volatile compounds in the wines was done in duplicate, and as the fermentations were done in duplicate, the results shown for these compounds were the mean of 4 analyses.

\subsection{Statistical analysis}

The statistical analysis of the volatile compounds data was performed using SPSS Version 17.0 statistical package for Windows (SPSS, Chicago, USA), by means mainly of one-way analysis of varianza (ANOVA). 


\section{Results and discussion}

\subsection{Oenological parameters of grape samples during ripening}

Table 1 shows the oenological parameters in Monastrell organic and non-organic grapes during ripening. At first, in Monastrell organic samples the weight of 100 berries was higher than in Monastrell non-organic, but from 12th September, Monastrell non-organic continued rising and Monastrell organic dismissed. Therefore in Monastrell non-organic the weight of 100 berries was higher at the end of ripening, probably due to the irrigation. ${ }^{\circ}$ Baumé/total acidity index is used as a tool to measuring the industrial maturity grape, indicating, in general, the highest index the best value for harvesting. As can be seen in Table 1, Monastrell organic samples showed higher values for this index than Monastrell nonorganic, although at the end of ripening the differences dismissed. The $\mathrm{pH}$ of the grapes evolved in the same way in both types of Monastrell, showing a tendency to increase throughout the ripening until the last point, in which slightly decreased. Finally, the color index also showed similar evolution in both types of grapes, but with the highest values in Monastrell organic, which could be related to the weight of berries, which being higher for the Monastrell non-organic, resulted in a lower concentration of phenolic compounds.

\begin{tabular}{ccccc}
\hline Samples & $\begin{array}{c}\text { Weight of } 100 \\
\text { berries }(\mathrm{g})\end{array}$ & $\begin{array}{c}{ }^{\circ} \text { Baumé/total } \\
\text { acidity }\end{array}$ & $\mathrm{pH}$ & $\begin{array}{c}\text { Color } \\
\text { index }\end{array}$ \\
\hline $\begin{array}{c}\text { Monastrell non-organic } \\
\text { 08-aug }\end{array}$ & 90 & 0.24 & 2.72 & 0.83 \\
23-aug & 131 & 1.17 & 2.96 & 1.66 \\
05-sep & 175 & 1.29 & 3.13 & 2.16 \\
12-sep & 146 & 1.51 & 3.28 & 2.17 \\
19-sep & 168 & 1.87 & 3.37 & 3.18 \\
27-sep & 188 & 2.14 & 3.28 & 2.78 \\
Monastrell organic & & & & \\
08-aug & 102 & 0.56 & 2.96 & 2.01 \\
23-aug & 145 & 2.16 & 3.02 & 4.07 \\
05-sep & 182 & 2.32 & 3.21 & 5.86 \\
12-sep & 151 & 2.71 & 3.27 & 5.20 \\
19-sep & 138 & 3.09 & 3.40 & 8.72 \\
27-sep & 150 & 2.36 & 3.17 & 5.34 \\
\hline
\end{tabular}

a Total acidity expressed as $\mathrm{g} / \mathrm{L}$ tartaric acid.

Table 1. Oenological parameters of the different samples during grape ripening.

\subsection{Nitrogenous fractions of grape samples during ripening}

Table 2 shows the evolution of ammonium, amino and assimilable nitrogen concentrations, and total amino acids during grape ripening. The ammonium is the nitrogen source preferred by yeast, as it is the first nitrogen compound that they assimilate during alcoholic fermentation (Cooper, 1982). The ammonium nitrogen concentration decreased after veraison, which occurred in August, between 1 and 8 in Monastrell organic and between 8 and 23, in Monastrell non-organic grapes. Before veraison, approximately the half of nitrogen in the pulp is as ammonium nitrogen, but after veraison it is transformed in amino acids and its concentration dismissed (Blouin \& Guimberteau, 2004). After veraison, 
ammonium concentration changed and at harvest moment (27-sep) was higher in Monastrell non-organic than in organic grapes (Table 2). Ammonium content in the lasts sampling was low in both types of Monastrell, but it was between the usual limits for this compound in grapes (5-325 mg N/L) (Bell \& Henschke, 2005).

\begin{tabular}{ccccc}
\hline Samples & $\begin{array}{c}\text { Ammonium } \\
\text { nitrogen }\end{array}$ & $\begin{array}{c}\text { Amino } \\
\text { nitrogen }\end{array}$ & $\begin{array}{c}\text { Assimilable } \\
\text { nitrogen }\end{array}$ & $\begin{array}{c}\text { Total amino } \\
\text { acids }\end{array}$ \\
\hline Monastrell non-organic & & & & \\
08-aug & $68.0 \pm 1.0$ & $85.0 \pm 2.0$ & $151.0 \pm 4.0$ & $501.0 \pm 15.0$ \\
23-aug & $48.0 \pm 1.0$ & $156.0 \pm 6.0$ & $199.0 \pm 6.0$ & $746.0 \pm 27.0$ \\
05-sep & $32.3 \pm 0.4$ & $141.0 \pm 2.0$ & $172.0 \pm 2.0$ & $645.0 \pm 5.0$ \\
12-sep & $34.0 \pm 1.0$ & $141.0 \pm 4.0$ & $174.0 \pm 5.0$ & $628.0 \pm 19.0$ \\
19-sep & $20.2 \pm 0.3$ & $62.1 \pm 0.8$ & $82.0 \pm 1.0$ & $285.0 \pm 4.0$ \\
27-sep & $25.0 \pm 1.0$ & $123.0 \pm 4.0$ & $148.0 \pm 5.0$ & $557.0 \pm 17.0$ \\
Monastrell organic & & & & \\
08-aug & $18.8 \pm 0.4$ & $61.0 \pm 1.0$ & $78.0 \pm 2.0$ & $333.0 \pm 5.0$ \\
23-aug & $14.9 \pm 0.2$ & $56.1 \pm 0.5$ & $69.9 \pm 0.6$ & $291.0 \pm 3.0$ \\
05-sep & $22.2 \pm 0.6$ & $85.0 \pm 2.0$ & $106.0 \pm 3.0$ & $408.0 \pm 11.0$ \\
12-sep & $15.6 \pm 0.0$ & $49.6 \pm 0.0$ & $65.1 \pm 0.1$ & $260.4 \pm 0.2$ \\
19-sep & $28.5 \pm 0.4$ & $155.0 \pm 2.0$ & $183.0 \pm 2.0$ & $720.0 \pm 7.0$ \\
27-sep & $15.7 \pm 0.0$ & $65.1 \pm 0.1$ & $78.8 \pm 0.1$ & $346.1 \pm 0.2$ \\
\hline
\end{tabular}

Table 2. Nitrogenous fractions ( $\mathrm{mg} \mathrm{N} / \mathrm{L}$ ) and total amino acids $(\mathrm{mg} / \mathrm{L})$ of the different samples during grape ripening. All parameters are given with their standard deviation $(n=2)$.

The evolution of amino and assimilable nitrogen concentration was similar (Table 2). Both nitrogen fractions increased after veraison in Monastrell non-organic grapes. In both types of samples it was observed that amino and assimilable nitrogen decreased. This decreasing occurred in Monastrell organic grapes at the end of ripening and in Monastrell non-organic in September, between the 12 and the 19, and then increased at the end of ripening. At the harvest moment, amino and assimilable nitrogen concentration were far higher in Monastrell non-organic than in Monastrell organic grapes. These differences in nitrogen compound contents can be due to the different fertilizer and irrigation. The fertilization of Monastrell organic grapevines provided more nitrogen than that of Monastrell organic, and moreover the last grapes only received nitrogen once. The irrigation also helps to the nitrogen assimilation by the plant. In order to the alcoholic fermentation evolved properly, musts have to contain assimilable nitrogen concentration above $140 \mathrm{mg} \mathrm{N} / \mathrm{L}$ (Bely et al., 1990). This did not occur in the case of Monastrell organic (Table 2), which could cause that its fermentation was slower than that of Monastrell non-organic, as lately will be discussed.

Both Monastrell, non-organic and organic, showed higher total amino acid concentration at the end of grape ripening than at the beginning, which indicates these compounds were accumulated throughout the ripening (Table 2). Monastrell non-organic grapes showed higher total amino acid concentration than Monastrell organic at harvest moment, probably due to the different irrigation and fertilization, as we write above. This is important as these compounds affect the fermentative kinetics (Bisson, 1991) and the formation of volatile compounds during alcoholic fermentation (Rapp \& Versini, 1991). Amino acid concentration at harvest depends on edaphoclimatic conditions and agronomic practices, while amino acid 
profile mainly depend on variety and zone (Garde-Cerdán et al., 2009a; Hernández-Orte et al., 1999; Huang \& Ough, 1991).

\subsection{Free amino acid content in the grape samples during ripening}

Figure 1 shows the amino acid concentration in organic and non-organic samples during grape ripening. Monastrell non-organic grapes had higher concentration than Monastrell organic in all the amino acids at the harvest moment and, in general, during grape ripening, except one week before harvest, date in which Monastrell organic showed the highest concentration in many of them.

\section{a) Monastrell non-organic}

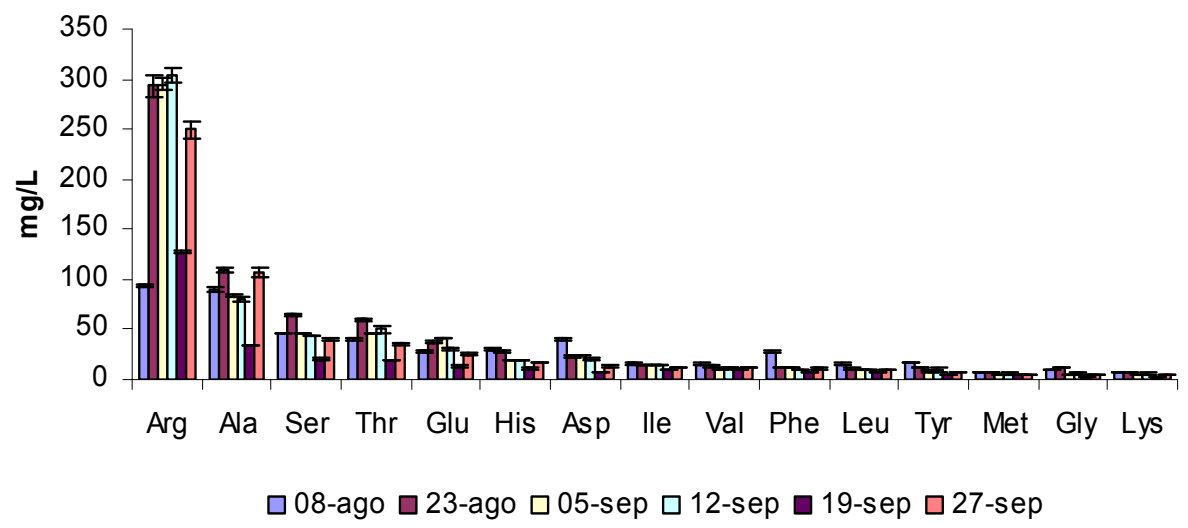

b) Monastrell organic

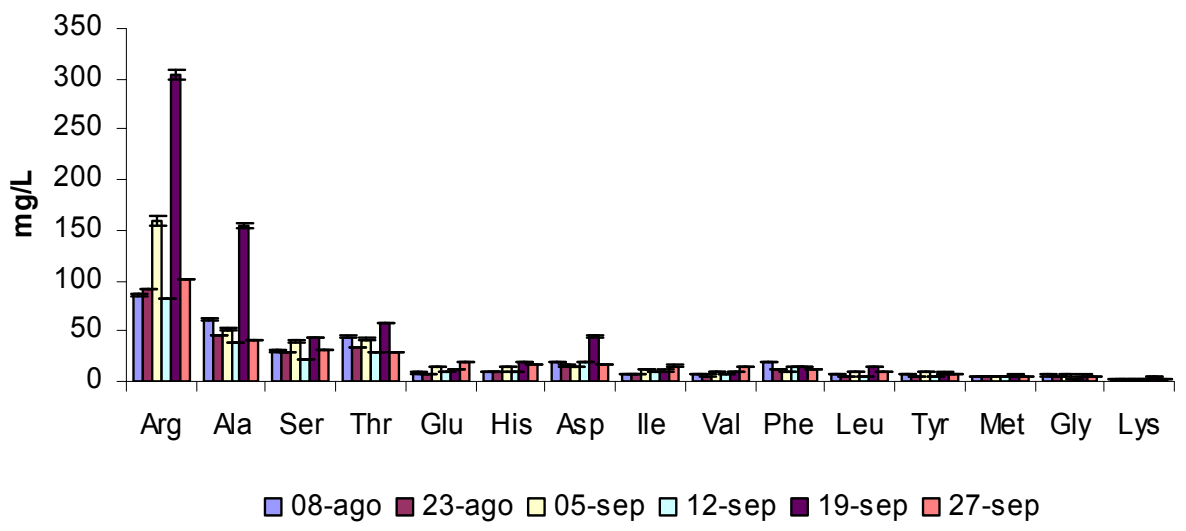

Fig. 1. Amino acid concentration (mg/L) in both types of samples during grape ripening. All parameters are given with their standard deviation $(n=2)$. 
In both types of samples the majority and minority amino acids and so the qualitative composition was the same. Arginine was the most abundant amino acid in both types of samples, as other authors have shown (Garde-Cerdán et al., 2008; Henschke \& Jiranek, 1993). This is important since arginine is one of the amino acids preferred by yeast as nitrogen source (Bell \& Henschke, 2005; Cooper, 1982). The concentration of this amino acid in both types of Monastrell was higher at the end than at the beginning of ripening. Alanine, the second amino acid most abundant, also was higher at the end than at the beginning of ripening in Monastrell non-organic, but no in Monastrell organic. For some of the aroma compounds that are produced in the alcoholic fermentation, the precursor amino acids (threonine, isoleucine, leucine, valine, phenylalanine, tyrosine and methionine) showed lower concentrations at the end than at the beginning of ripening in Monastrell non-organic. However, in Monastrell organic, although threonine and phenylalanine also dismissed their concentration, the others showed concentration slightly higher at the end than at the beginning of ripening. These amino acids are very important since they can affect the aromatic quality of wines, because higher alcohols come from them directly (n-propanol from threonine, 2-methyl-1-butanol from isoleucine, 3-methyl-1-butanol from leucine, isobutanol from valine, 2-phenylethanol from phenylalanine, and 3-methylthio-1-propanol from methionine) and some of studied esters indirectly, as they come from these higher alcohols. The concentration of the rest of amino acids (serine, glutamic acid, histidine, aspartic acid, glycine and lysine) decreased or remained constant in both types of samples, except glutamic acid and histidine in Monastrell organic, concentrations of which increased at the end of ripening. All of these amino acids are considered good nitrogen sources for yeast (Garde-Cerdán et al., 2008; Henschke \& Jiranek, 1993), except lysine and glycine, which are not considered good nitrogen sources for $S$. cerevisiae, although they could be metabolized by other microorganism, such as non-Saccharomyces yeast (Cooper, 1982).

The most abundant amino acid, arginine, was higher at the end of ripening than at the beginning. For this reason, as we write above, the total amount of amino acids in both types of samples -although slightly in Monastrell organic- was higher at the end of ripening than at the beginning, despite the rest of amino acids separately did not show this tendency.

\subsection{Oenological parameters of wines and kinetics of fermentation}

Wines from Monastrell non-organic grapes showed lower total and volatile acidity than those elaborated with Monastrell organic grapes (Table 3). In both types of samples volatile acidity was low and below levels detrimental to wine quality (Ribéreau-Gayon et al., 2006). The $\mathrm{pH}$ of wines was lower in Monastrell organic than in non-organic samples. At the end of fermentation almost all the sugars in the medium were consumed, remaining in both types of samples very low concentration of them.

\begin{tabular}{lcccccc}
\hline Sample & $\begin{array}{c}\text { Total } \\
\text { acidity } \\
(\mathrm{g} / \mathrm{L})^{\mathrm{a}}\end{array}$ & $\begin{array}{c}\text { Volatile } \\
\text { acidity } \\
(\mathrm{g} / \mathrm{L})^{\mathrm{b}}\end{array}$ & $\mathrm{pH}$ & $\begin{array}{c}\text { Reducing } \\
\text { sugars } \\
(\mathrm{g} / \mathrm{L})\end{array}$ & $\begin{array}{c}\text { Alcohol } \\
(\mathrm{v} / \mathrm{v}, \%)\end{array}$ & $\begin{array}{c}\text { Color } \\
\text { index }\end{array}$ \\
\hline Monastrell non-organic & 5.55 & 0.19 & 3.75 & 0.53 & 10.21 & 2.72 \\
Monastrell organic & 6.31 & 0.35 & 3.59 & 0.83 & 12.79 & 7.24 \\
\hline
\end{tabular}

a As g/L tartaric acid. ${ }^{b}$ As g/L acetic acid.

Table 3. Oenological parameters of the wines elaborated from the different grape samples. 
Wines elaborated with Monastrell organic grapes had higher alcoholic degree than those from Monastrell non-organic (Table 3), as these grapes showed lower concentration of sugars in the initial musts (Monastrell non-organic: $161 \mathrm{~g} / \mathrm{L}$; Monastrell organic: $210 \mathrm{~g} / \mathrm{L}$ ). Likewise, color index was higher in wines from Monastrell organic than in those from Monastrell non-organic. This was due to grapes used to elaborate them showed the same trend (Table 1), and the higher color index in musts, the higher color index in wines (Franco \& Iñiguez, 1999). Therefore, we can say that wines from Monastrell organic grapes will have the best color.
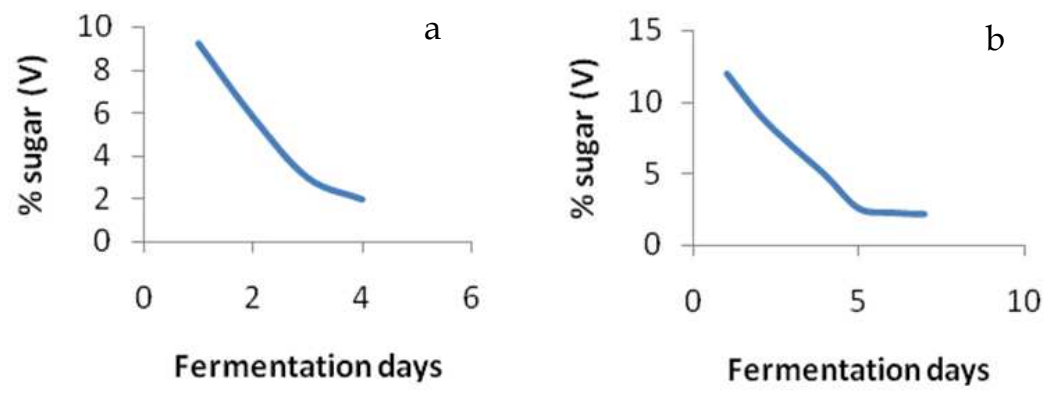

Fig. 2. Fermentation kinetics (a. Monastrell non-organic; b. Monastrell organic).

In Monastrell organic samples fermentation was slower (6 days) than in Monastrell nonorganic (4 days) (Figure 2). This was due to nitrogen compounds content were higher in musts from Monastrell non-organic than in those from Monastrell organic (Table 2), and to Monastrell organic musts showed higher reducing sugars concentration than non-organic ones. Therefore, fermentation kinetic was favored when the medium showed higher nitrogen content and lower carbon content.

\subsection{Nitrogenous fractions of the wines}

Table 4 shows the nitrogen fraction of the wines from Monastrell organic and non-organic. As we write above, the ammonium is the first nitrogen source used by yeast. For this reason, in the fermentation carried out with Monastrell non-organic all the ammonium nitrogen had been consumed and in those from Monastrell organic only rested $1.6 \mathrm{mg} / \mathrm{L}$ in the wines. However, if we observed the Table 2, we can see that grapes from Monastrell organic presented at harvest moment lower content in ammonium nitrogen, so the yeast had consumed less quantity in this fermentation. Moreover, low concentrations of ammonium in the initial must could promote an increase of higher alcohols in the wines, because the yeasts are forced to use the amino acids of must as nitrogen source (Usseglio-Tomasset, 1998). Therefore, it would be expected that wines from Monastrell organic show higher quantity of higher alcohols than wines from Monastrell non-organic.

\begin{tabular}{cccc}
\hline Sample & $\begin{array}{c}\text { Ammonium } \\
\text { nitrogen }\end{array}$ & $\begin{array}{c}\text { Amino } \\
\text { nitrogen }\end{array}$ & $\begin{array}{c}\text { Assimilable } \\
\text { nitrogen }\end{array}$ \\
\hline $\begin{array}{c}\text { Monastrell non-organic } \\
\text { Monastrell organic }\end{array}$ & - & $58.5 \pm 4.1$ & $17.5 \pm 0.4$ \\
\hline
\end{tabular}

Table 4. Nitrogenous fractions (mg N/L) of the wines. All parameters are given with their standard deviation $(n=4)$. 
As we can calculate with data from Tables 2 and 4, the percentage of amino nitrogen consumed during the alcoholic fermentation carried out with Monastrell organic samples was slightly higher than those carried out with Monastrell non-organic (59.4\% in the first and $52.4 \%$ in the last). However, the total consumption of assimilable nitrogen was far higher in the fermentation of Monastrell non-organic samples than in the fermentation carried out with organic samples.

\subsection{Consumption of amino acids during the alcoholic fermentation}

During the alcoholic fermentation, both in Monastrell non-organic and organic, the most consumed amino acids were arginine, alanine, serine, and threonine (Table 5), and these compounds showed also the highest concentration in the grapes at harvest (Figure 1). All of them are considered good nitrogen sources for S. cerevisiae, so this yeast consume them priority during alcoholic fermentation (Barrajón-Simancas et al., 2011; Garde-Cerdán et al., 2008). Regarding to amino acid precursors of higher alcohols (phenylalanine, leucine, isoleucine, valine, tyrosine and methionine), their consumption were higher in Monastrell organic fermentation, with exception of methionine and phenylalanine (Table 5). Glycine and lysine, which were the amino acids with the lowest concentration in grapes at harvest, were excreted or consumed at very small amounts during alcoholic fermentation, probably due to $S$. cerevisiae does not metabolize them.

Yeast, during the alcoholic fermentation, metabolized $78 \%$ of the amino acids presented in the initial Monastrell non-organic must and $71 \%$ of those in initial organic must. As yeast inoculated in both fermentations was the same, the different consumption of nitrogen compounds could be due to yeast adaptation to the initial medium conditions, that is to say, the higher amino acids quantity, the higher consumption (Garde-Cerdán et al., 2011).

\begin{tabular}{ccc}
\hline & Monastrell non-organic & Monastrell organic \\
\hline Aspartic acid & $7 \pm 2$ & $6.2 \pm 0.6$ \\
Glutamic acid & $-2.9 \pm 0.4$ & $10.29 \pm 0.03$ \\
Serine & $35 \pm 1$ & $25.6 \pm 0.1$ \\
Histidine & $10.6 \pm 0.2$ & $11.2 \pm 0.4$ \\
Glycine & $-3.8 \pm 0.8$ & $-2.3 \pm 0.4$ \\
Threonine & $31 \pm 1$ & $28.6 \pm 0.2$ \\
Arginine & $240 \pm 8$ & $89.2 \pm 0.8$ \\
Alanine & $89 \pm 5$ & $27 \pm 2$ \\
Tyrosine & $2.2 \pm 0.5$ & $4.0 \pm 0.2$ \\
Valine & $-7 \pm 3$ & $16.1 \pm 0.5$ \\
Methionine & $1.68 \pm 0.06$ & $0.9 \pm 0.3$ \\
Isoleucine & $9.6 \pm 0.1$ & $13.1 \pm 0.3$ \\
Leucine & $6.0 \pm 0.2$ & $10.6 \pm 0.5$ \\
Phenylalanine & $6.0 \pm 0.3$ & $6.1 \pm 0.5$ \\
Lysine & $0.48 \pm 0.02$ & $-5.1 \pm 0.6$ \\
Total amino acids & $434 \pm 18$ & $245 \pm 2$ \\
\hline
\end{tabular}

All parameters are given with their standard deviation $(n=4)$.

Table 5. Amino acid consumption (mg/L) during alcoholic fermentation of Monastrell nonorganic and organic musts. 


\subsection{Formation of volatile compounds in the alcoholic fermentation}

Figure 3 shows the concentration of higher alcohols in wines elaborated from organic and non-organic samples. Higher alcohols have not been considered as factors of wine quality, as they posses fusel-like odors (Mallouchos et al., 2002). However, they contribute to the wine aromatic complexity in moderate concentrations ( $<400 \mathrm{mg} / \mathrm{L}$; Ribéreau-Gayon et al., 2006). Monastrell non-organic showed a quantity of total higher alcohols close to this limit, but the concentration of these in Monastrell organic were higher. As we write above, the great formation of higher alcohols in the alcoholic fermentation could be due to the low ammonium concentration in the initial musts, especially in Monastrell organic (Table 2). Monastrell organic showed higher concentration than non-organic in propanol, 2-hexen-1-ol and 2-phenylethanol, with this last compound being the only alcohol described at a sensory level in pleasant terms (Versini et al., 1994). In the case of isoamyl alcohols, 2-methyl-1butanol and 3-methyl-1-butanol and isobutanol, their differences in both types of wine were not significant. The concentrations of 3-methylthio-1-propanol and 1-hexanol were lower in organic than in non-organic wines. Monastrell organic had higher concentration of total alcohols than non-organic, which may be related to the higher sugar content (Butzke, 1998; Marchetti \& Guerzoni, 1987; Lorenzo et al., 2008). Moreover, Monastrell organic grapes were lower nitrogen content than non-organic grapes (Table 2), which can explain the less synthesis of alcohols in the fermentation of non-organic grapes. This is because, as we have written in the section 3.5., the higher nitrogen concentration in the initial must, the less alcohol synthesis during the alcoholic fermentation (Torrea et al., 2003; Ugliano \& Henschke, 2009; Vilanova et al., 2007).

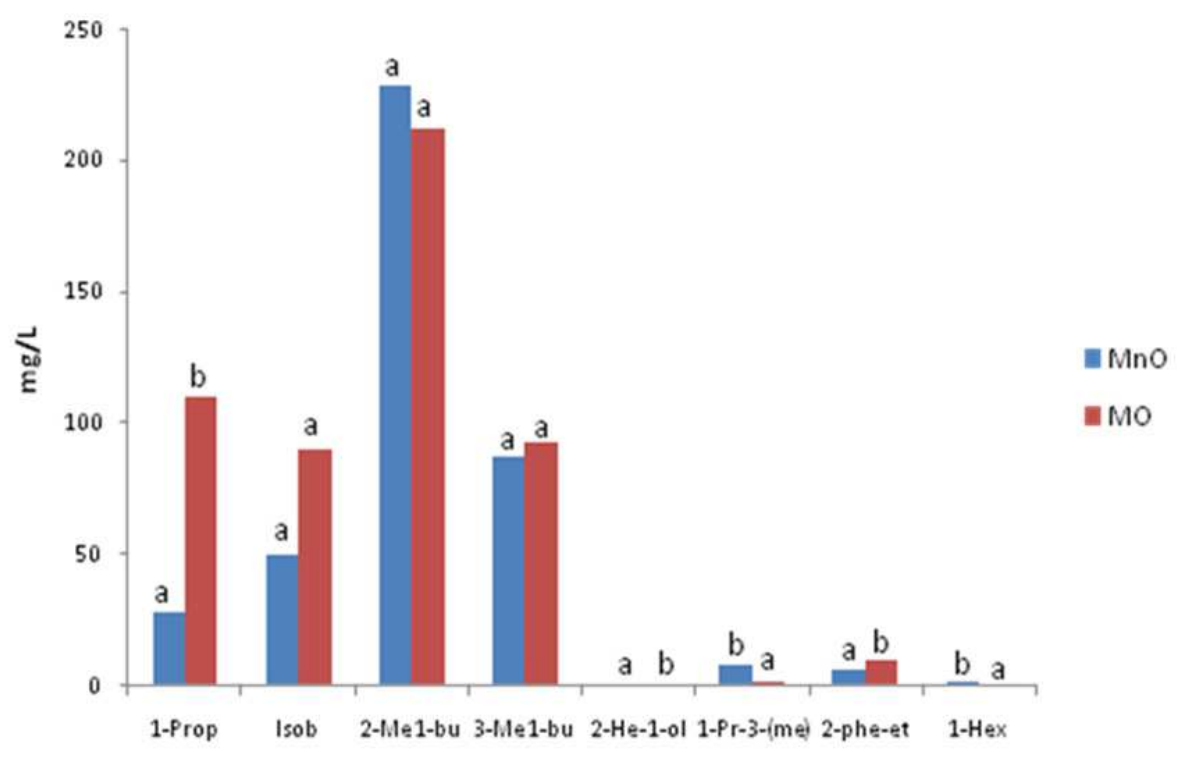

Fig. 3. Alcohol concentrations (mg/L) for Monastrell organic (MO) and Monastrell nonorganic $(\mathrm{MnO})$. For each compound, different letters indicate significant differences between the samples $(\mathrm{p}<0.05)$. 


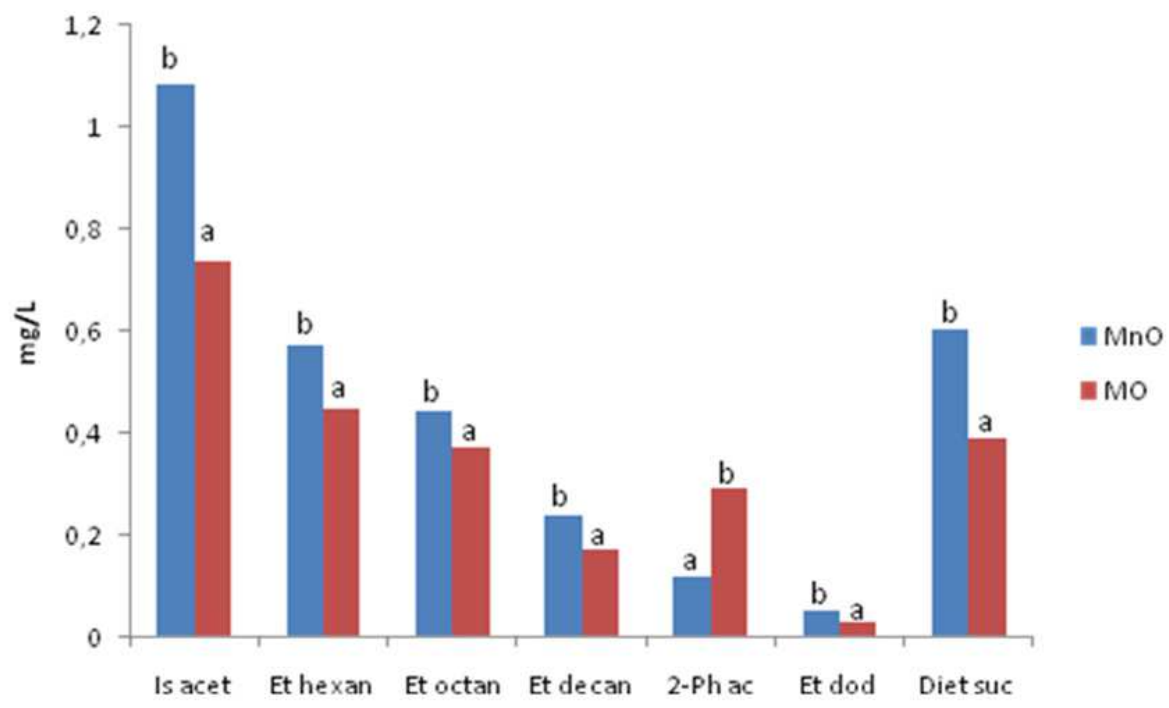

Fig. 4. Ester concentrations (mg/L) for Monastrell organic (MO) and Monastrell non-organic $(\mathrm{MnO})$. For each compound, different letters indicate significant differences between the samples $(\mathrm{p}<0.05)$.

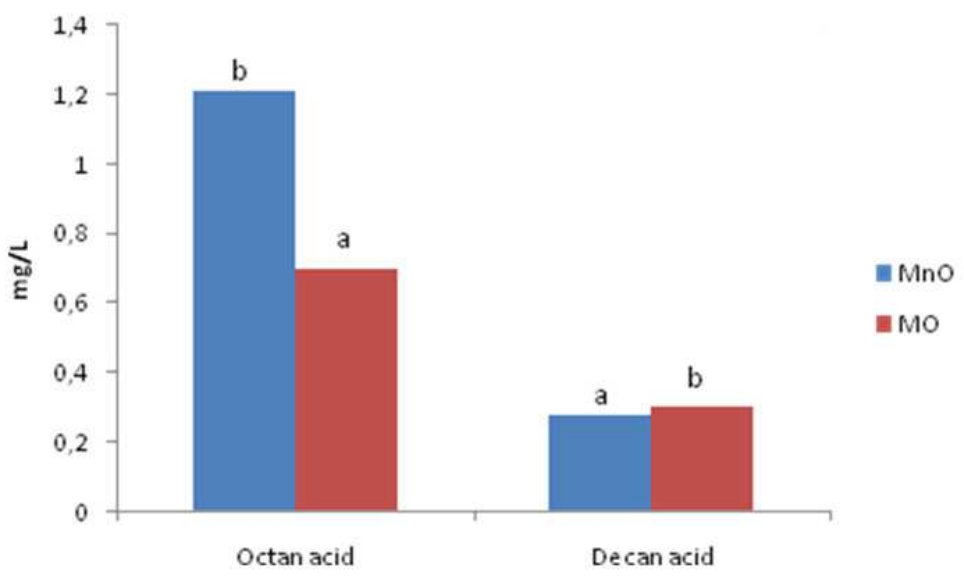

Fig. 5. Acid concentrations (mg/L) for Monastrell organic (MO) and Monastrell non-organic $(\mathrm{MnO})$. For each compound, different letters indicate significant differences between the samples $(\mathrm{p}<0.05)$.

Esters are very important compounds on wine quality, as they are the main compounds responsible for the fruity and floral character in wines (Ferreira et al., 1995; Franciolo et al., 2003). All the esters studied showed higher concentration for Monastrell non-organic wines, 
except 2-phenylethyl acetate (Figure 4). Thus, the concentration of total esters was higher in non-organic than in organic samples. This is in accordance with the results obtained by Moyano et al. (2009) for Sherry wines, who explain the higher production of esters in nonorganic due to the higher concentrations of $\mathrm{SO}_{2}$ in this type of wines, like Shinohara (1986) and Valcarcel et al. (1990).

Figure 5 shows the concentration of acids in wines from organic and non-organic samples. In the same way that alcohols, although these compounds are not associated with wine quality, their presence plays an important role in the complexity of the aroma (Shinohara, 1985). Monastrell non-organic showed higher concentration of octanoic acid than organic samples, and the concentration of decanoic acid was slightly higher in Monastrell organic. Therefore, the concentrations of acids in these samples are also in accordance with Moyano et al. (2009).

\section{Conclusion}

The differences in irrigation and fertilization in Monastrell organic and non-organic grapes probably led to the different composition in nitrogen compounds and amino acids in both types of samples. And this, in its turn, carried out to the different kinetics of fermentation, being the alcoholic fermentation slower in Monastrell organic than in non-organic musts. According to this, the optimum harvest moment, in terms of nitrogen composition of the must, would be different in both types of samples, being later in Monastrell non-organic. The consumption of nitrogen compounds during the alcoholic fermentation by the yeasts was directly related with their initial concentration in the must. The amino acid profile and amino acids most consumed were the same in both types of samples. Finally, about the formation of volatile compounds, the concentration of total alcohols was higher in Monastrell organic wines, which could be due to the low ammonium concentration in the initial musts. However, the concentration of esters and acids was higher in Monastrell nonorganic, which was related with the higher amino acid consumption in this type of sample.

\section{Acknowledgment}

Many thanks for the financial support given by the Junta de Comunidades de Castilla-La Mancha to the Project PII1I09-0157-9307 and to the FPI scholarship for A.M.M.-G. T.G.-C. thanks to the Ministerio de Ciencia e Innovación for the contract of the project AGL2009-08950 and also to the Consejo Superior de Investigaciones Científicas (CSIC) for the JAE-Doc contract. We wish to express our gratitude to Kathy Walsh for proofreading the English manuscript.

\section{References}

Arias-Gil, M., Garde-Cerdán, T. \& Ancín-Azpilicueta, C. (2007). Influence of addition of ammonium and different amino acid concentrations on nitrogen metabolism in spontaneous must fermentation. Food Chemistry, Vol.103, pp. 1312-1318, ISSN 03088146

Barbosa, C., Falco, V., Mendes-Faia, A. \& Mendes-Ferreira, A. (2009). Nitrogen addition influences formation of aroma compounds, volatile acidity and ethanol in nitrogen deficient media fermented by Saccharomyces cerevisiae wine strains. Journal of Bioscience and Bioengineering, Vol.108, pp. 99-104, ISSN 1389-1723 
Barrajón-Simancas, N., Giese, E., Arévalo-Villena, M., Úbeda, J. \& Briones, A. (2011). Amino acid uptake by wild and commercial yeasts in single fermentations and cofermentations. Food Chemistry, Vol.127, pp. 441-446, ISSN 0308-8146

Bell, S.J. \& Henschke, P.A. (2005). Implications of nitrogen nutrition for grapes, fermentation and wine. Australian Journal of Grape and Wine Research, Vol.11, pp. 242-295, ISSN $1322-7130$

Bely, M., Sablayrolles, J.M. \& Barre, P. (1990). Automatic detection of assimilable nitrogen deficiencies during alcoholic fermentation in enological conditions. Journal of Fermentation and Bioengineering, Vol.70, pp. 246-252, ISSN 1389-1723

Bisson, L.F. (1991). Influence of nitrogen on yeast and fermentation of grapes, Proceedings of the International Symposium on Nitrogen in Grapes and Wine, pp. 78-89, ISBN 09630711-0-6, Seattle, Washington, USA

Blouin, J. \& Guimberteau, G. (2004). Maduración y Madurez de la Uva, Ediciones MundiPrensa, ISBN 8484764486, Madrid, Spain

Bouloumpasi, E., Souflerops, E.H., Tsarchopoulos, C. \& Biliaderis, C.G. (2002). Primary amino acid composition and its use in discrimination of Greek red wines with regard to variety and cultivation region. Vitis, Vol.4, pp. 195-202, ISSN 0042-7500

Butzke, C.E. (1998). Survey of yeast assimilable nitrogen status in musts from California, Oregon, and Washington. American Journal of Enology and Viticulture, Vol.49, pp. 220-224, ISSN 0002-9254

Carrau, F.M., Medina, K., Fariña, L., Boido, E., Henschke, P.A. \& Dellacassa, E. (2008). Production of fermentation aroma compounds by Saccharomyces cerevisiae wine yeasts: effects of yeast assimilable nitrogen on two model strains. FEMS Yeast Research, Vol.8, pp. 1196-1207, ISSN 1567-1356

Cooper, T.G. (1982). Nitrogen metabolism in Saccharomyces cerevisiae, In: The Molecular Biology of the Yeast Saccharomyces. Metabolism and Gene Expression, J.N. Strathern, E.W. Jones \& J.B. Broach, (Eds.), pp. 399-462, Cold Spring Harbor Laboratory, ISBN 0879691492, New York, USA

ECC (1990). Commission Regulation VO 2676/90 concerning the establishment of common analytical methods in the sector of wine. Official Journal of the European Community, L272(3), pp. 1-192

Ferreira, V., Fernández, P., Peña, C., Escudero, A. \& Cacho, J. F. (1995). Investigation on the role played by fermentation esters in the aroma of young Spanish wines by multivariate analysis. Journal Science of Food Agriculture, Vol.67, pp. 381- 392, ISSN 0022-5142

Franciolo, S., Torrens, J., Riu-Aumatell, M., López-Tamames, E. \& Buxaderas, S. (2003). Volatile compounds by SPME-GC as age markers of sparkling wines. American Journal of Enology and Viticulture, Vol.53, pp. 158-162, ISSN 0002-9254

Franco, E. \& Iñiguez, M. (1999). Estudio de la relación entre el color de la uva tinta y el color del vino. Viticultura/Enolología Profesional, Vol.63, pp. 23-34, ISSN: 1131-5679

Garde-Cerdán, T. \& Ancín-Azpilicueta, C. (2008). Effect of the addition of different quantities of amino acids to nitrogen-deficient must of the formation of esters alcohols, and acids during wine alcoholic fermentation. LWT-Food Science and Technology, Vol.41, pp. 501-510, ISNN 0023-6438

Garde-Cerdán, T., Arias-Gil, M., Marsellés-Fontanet, A.R. Salinas, M.R., Ancín-Azpilicueta, C. \& Martín-Belloso, O. (2008). Study of the alcoholic fermentation of must 
stabilized by pulsed electric fields. Effect of $\mathrm{SO}_{2}$, In: Progress in Food Chemistry, E.N. Koeffer, (Ed.), pp. 73-103, Nova Science Publishers, Inc, ISBN 978-1-60456-303-0, New York, USA

Garde-Cerdán, T., Lorenzo, C., Lara, J.F., Pardo, F., Ancín-Azpilicueta, C. \& Salinas, M.R. (2009a). Study of the evolution of nitrogen compounds during grape ripening. Aplication to differentiate grape varieties and cultivated systems. Journal of Agricultural and Food Chemistry, Vol.57, pp. 2410-2419, ISSN 0021-8561

Garde-Cerdán, T., Lorenzo, C., Carot, J.M., Esteve, M.D., Climent, M.D. \& Salinas, M.R. (2009b). Differentiation of barrel-aged wines according to their origin, variety, storage time and enological parameters using fermentation products. Food Control, Vol.20, pp. 269-276, ISSN 0956-7135

Garde-Cerdán, T., Martínez-Gil, A.M., Lorenzo, C., Lara, J.F., Pardo, F. \& Salinas, M.R. (2011). Implications of nitrogen compounds during alcoholic fermentation from some grape varieties at different maturation stages and cultivation systems. Food Chemistry, Vol.124, pp. 106-116, ISSN 0308-8146

Héberger, K., Csomós, E. \& Simon-Sarkadi, L. (2003). Principal component and linear discriminant analyses of free amino acids and biogenic amines in Hungarian wines. Journal of Agricultural and Food Chemistry, Vol.51, pp. 8055-8060, ISSN 0021-8561

Henschke, P.A. \& Jiranek, V. (1993). Metabolism of nitrogen compounds. In: Wine Microbiology and Biotechnology, G.H. Fleet, (Ed.), pp. 77-164. Harwood Academic Publishers, ISBN 10-0415278503, Victoria, Australia

Hernández-Orte, P., Guitart, A. \& Cacho, J. (1999). Changes in the concentration of amino acids during the ripening of Vitis vinifera Tempranillo variety from the Denomination d'Origine Somontano (Spain). American Journal of Enology and Viticulture, Vol.50, pp. 144-154, ISSN 0002-9254

Huang, Z. \& Ough, C.S. (1991). Amino acid profiles of commercial grape juices and wines. American Journal of Enology and Viticulture, Vol.42, pp. 261-267, ISSN 0002-9254

Lambrechts, M.G. \& Pretorius, I.S. (2000). Yeast and its importance to wine aroma. A review. South African Journal of Enology and Viticulture, Vol.21, pp. 97-129, ISNN 0253-939X

Lorenzo, C., Pardo, F., Zalacain, A., Alonso, G.L. \& Salinas, MR. (2008). Differentiation of cowinemaking wines by their aroma composition. European Food Research and Technology, Vol.227, pp. 777-87, ISNN 1438-2377

Mallouchos, A., Komaitis, M., Koutinas, A. \& Kanellaki, M. (2002). Investigation of volatiles evolution during the alcoholic fermentation of grape must using free and immobilized cells with the help of solid phase microextraction (SPME) headspace sampling. Journal of Agricultural and Food Chemistry, Vol.50, pp. 3840-3848, ISSN 0021-8561

Marchetti, R. \& Guerzoni, M.E. (1987). Effets de l'interaction souche de levure/composition $\mathrm{du}$ mout sur la production, au cours de la fermentation, de quelques métabolites volatils. Connaissance de la Vigne et du Vin, Vol.21, pp. 113-125, ISNN 0010-597X

Moreno-Arribas, M. V. \& Polo, M. C. (2009). Wine Chemistry and Biochemistry, Springer, ISBN 9780387741161, New York, USA

Moyano, L., Zea, L., Villafuerte, L. \& Medina, M. (2009). Comparison of odor-active compounds in Sherry wines processed from ecologically and conventionally grown Pedro Ximenez grapes. Journal of Agricultural and Food Chemistry, Vol.57, pp. 968973, ISSN 0021-8561 
Rapp A. \& Versini G. (1991). Influence of nitrogen compounds in grapes on aroma compounds in wine, Proceedings of the International Symposium on Nitrogen in Grapes and Wine, pp. 156-164, ISBN 0-9630711-0-6, Seattle, Washington, USA

Ribéreau-Gayon, P., Glories, Y., Maujean, A. \& Dubourdieu, D. (2006). Handbook of Enology, Volume 2. The Chemistry of Wine Stabilization and Treatments, Jonh Wiley \& Sons, Ltd, ISBN 9780470010372, Chichester, England

Ruiz-Larrea, F., López, R., Santamaría, P., Sacristán, M., Ruiz, M.C., Zarazaga, M., Gutiérrez, A.R. \& Torres, C. (1998). Soluble proteins and free amino nitrogen content in must and wine of cv. Viura in La Rioja. Vitis, Vol.37, pp. 139-142, ISSN 0042-7500

Shinohara, T. (1985). Gas chromatographic analysis of volatile fatty acids in wines. Agricultural and Biological Chemistry, Vol.49, pp. 2211-2212, ISSN 0002-1369

Shinohara, T. (1986). Factors affecting the formation of volatile fatty acids during grape must fermentation. Agricultural and Biological Chemistry, Vol.50, pp. 3197-3199, ISSN 00021369

Torrea, D., Fraile, P., Garde, T. \& Ancín, C. (2003). Production of volatile compounds in the fermentation of chardonnay musts inoculated with two strains of Saccharomyces cerevisiae with different nitrogen demands. Food Control, Vol.14, pp. 565-571, ISSN 0956-7135

Ugliano, M. \& Henschke, P.A. (2009). Yeasts and wine flavour, In: Wine Chemistry and Biochemistry, M.V. Moreno-Arribas \& M. C. Polo (Eds.), Springer, pp. 313-392, ISBN 9780387741161, New York, USA

Usseglio-Tomasset, L. (1998). Química Enológica, Ediciones Mundi-Prensa, ISBN 9788471147011, Madrid, Spain

Uthurry, C.A., Suárez Lepe, J.A., Lombardero, J. \& García del Hierro, J.R. (2007). Ethyl carbamate production by selected yeasts and lactic acid bacteria in red wine. Food Chemistry, Vol.94, pp. 262-270, ISSN 0308-8146

Valcarcel, M.J., Pérez, L., González, P. \& Domecq, B. (1990). Efecto de las prácticas enológicas en vendimia sobre las levaduras responsables de la fermentación de mostos de Jerez, IV: Estudio industrial. Alimentación, Equipos y Tecnología, Vol.3, pp. 171-174, ISSN 0212-1689

Valero, E., Millán, C., Ortega, J.M. \& Mauricio, J.C. (2003). Concentration of amino acids in wine after the end of fermentation by Saccharomyces cerevisiae strain. Journal of the Science of Food and Agriculture, Vol.83, pp. 830-835, ISSN 0022-5142

Versini, G., Orriols, I. \& Dalla Serra, A. (1994). Aroma components of Galician Albariño, Loureira and Godello wines. Vitis, Vol.33, pp. 165-170, ISSN 0042-7500

Vilanova, M., Ugliano, M., Varela, C., Siebert, T., Pretorius, I.S. \& Henschke, P.A. (2007). Assimilable nitrogen utilisation and production of volatile and non-volatile compounds in chemically defined medium by Saccharomyces cerevisiae wine yeasts. Applied Microbiology and Biotechnology, Vol.77, pp. 145-157, ISSN 0175-7598 


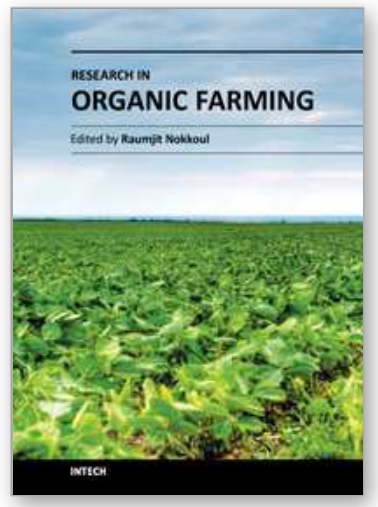

\author{
Research in Organic Farming \\ Edited by Dr. Raumjit Nokkoul
}

ISBN 978-953-307-381-1

Hard cover, 186 pages

Publisher InTech

Published online 16, December, 2011

Published in print edition December, 2011

This book has emerged as a consequence of the difficulties we experienced in finding information when we first started researching. The goal was to produce a book where as many existing studies as possible could be presented in a single volume, making it easy for the reader to compare methods, results and conclusions. As a result, studies from countries such as Thailand, Spain, Sweden, Lithuania, Czech, Mexico, etc. have been brought together as individual chapters, and references to studies from other countries have been included in the overview chapters where possible. We believe that this opportunity to compare results from different countries will open a new perspective on the subject, allowing the typical characteristics of Organic Agriculture and Organic Food to be seen more clearly. Finally, we would like to thank the contributing authors and the staff at InTech for their efforts and cooperation during the course of publication. I sincerely hope that this book will help researchers and students all over the world to reach new results in the field of Organic Agriculture and Organic Food.

\title{
How to reference
}

In order to correctly reference this scholarly work, feel free to copy and paste the following:

Teresa Garde-Cerdán, Cándida Lorenzo, Ana M. Martinez-Gil, José F. Lara, Francisco Pardo and M. Rosario Salinas (2011). Evolution of Nitrogen Compounds During Grape Ripening from Organic and Non-Organic Monastrell - Nitrogen Consumption and Volatile Formation in Alcoholic Fermentation, Research in Organic Farming, Dr. Raumjit Nokkoul (Ed.), ISBN: 978-953-307-381-1, InTech, Available from:

http://www.intechopen.com/books/research-in-organic-farming/evolution-of-nitrogen-compounds-during-graperipening-from-organic-and-non-organic-monastrell-nitrog

\section{INTECH}

open science | open minds

\section{InTech Europe}

University Campus STeP Ri

Slavka Krautzeka 83/A

51000 Rijeka, Croatia

Phone: +385 (51) 770447

Fax: +385 (51) 686166

www.intechopen.com

\section{InTech China}

Unit 405, Office Block, Hotel Equatorial Shanghai

No.65, Yan An Road (West), Shanghai, 200040, China

中国上海市延安西路65号上海国际贵都大饭店办公楼405单元

Phone: +86-21-62489820

Fax: $+86-21-62489821$ 
(C) 2011 The Author(s). Licensee IntechOpen. This is an open access article distributed under the terms of the Creative Commons Attribution 3.0 License, which permits unrestricted use, distribution, and reproduction in any medium, provided the original work is properly cited. 